\title{
Austrian and Russian constitutionalism: comprehensive analysis
}

\section{АВСТРИЙСКИЙ И РОССИЙСКИЙ КОНСТИТУЦИОНАЛИЗМ: КОМПЛЕКСНЫЙ АНАЛИЗ}

Received: March 7, 2021

\begin{abstract}
The article deals with some issues that characterize the Basic Laws of the Republic of Austria and the Russian Federation. When choosing the leading research method, the authors of this article were guided by the fundamental dialectical means of cognition, which is the ascent from the individual to the general. The comparison technique used in this case is based on a consistent understanding and analysis of similar conditions, rules and requirements for the Republic of Austria and the Russian Federation.

The applied historical and legal method made it possible to consider various historical events in motion, development, and in connection with modernity. The methods of analysis and synthesis are widely used in the work. As the main results of the study, we note the generalization of the most significant distinctive features that are the foundation of the Basic Laws of both federal states.
\end{abstract}

Keywords: constitutionalism, state, federalism, society, personality, rights, comparison.

\section{Introduction}

The subject of this study is the most significant provisions of the Basic Laws of the Republic of Austria and the Russian Federation. Despite
Accepted: May 30, 2021

Written by:

Alexander A. Gogin ${ }^{38}$

https://orcid.org/0000-0003-0949-4169

Anna N. Fedorova ${ }^{39}$

https://orcid.org/0000-0003-1348-5134

Ramil F. Vagapov ${ }^{40}$

https://orcid.org/0000-0002-4243-7775

Alexey V. Sergeev ${ }^{41}$

https://orcid.org/0000-0002-6670-1438

\section{Аннотация}

В статье рассматриваются некоторые вопросы, характеризующие основные законы Австрийской Республики и Российской Федерации. При выборе ведущего метода исследования авторы данной статьи руководствовались основным диалектическим средством познания - восхождением от индивидуального к общему. Используемая в данном случае методика сравнения основана на последовательном понимании и анализе схожих условий, правил и требований для Австрийской Республики и Российской Федерации.

Примененный историко-правовой метод позволил рассматривать различные исторические события в движении, развитии и в связи с современностью. В работе широко используются методы анализа и синтеза. В качестве основных результатов исследования отметим обобщение наиболее значимых отличительных черт, лежащих в основе Основных законов обоих федеральных земель.

Ключевые слова: конституционализм, государство, федерализм, общество, личность, права, сопоставление.

certain differences, they are comparable in a number of criteria. These acts contain those value aspects that not only reflect the essence of legal

\footnotetext{
${ }^{38}$ Doctor of Law, associate professor, Department of Civil Law and Procedure, Togliatti State University, Togliatti (Russia).

${ }^{39} \mathrm{PhD}$ in Law, associate professor, the Head of Civil Law and Procedure, Togliatti State University, Togliatti (Russia).

${ }^{40} \mathrm{PhD}$ in Law, associate professor, Department of Civil Law and Procedure, Togliatti State University, Togliatti (Russia).

${ }^{41} \mathrm{PhD}$ in Law, associate professor, Department of Civil Law and Procedure, Togliatti State University, Togliatti (Russia).
} 
doctrines, but also the conditions for their practical implementation.

The object of the research is a system of legal regulations that form and implement the vital rights, freedoms and interests of citizens of both countries at the current stage of social development. This takes into account both the need and the need to improve them and effectively protect them from various negative challenges and threats.

The relevance of the work is due to the polemic nature of the problems under study, since the changes made to the Federal Constitutional Law of Austria in 2008 and to the Constitution of the Russian Federation in 2020 caused mixed assessments among many representatives of the social strata of both countries. However, these amendments, regardless of their differences, in their essence are intended to serve as a supplement to the time-tested, previously fixed basic constitutional principles.

\section{Theoretical framework}

Before considering the main issues of the topic, it is necessary to conduct a brief historical review of the events of a century ago. This will allow us to better understand a number of relevant aspects related to the legislative and other processes that took place in Austria and the Russian Federation, although in different time periods.

After the end of the First World War, the peoples of certain European countries faced the question of creating legislative acts that correspond to the interests of the vast majority of citizens, and take into account the prevailing realities of that era. These problems were most acute in the new subjects of the world community that emerged on the territory of the former Austro-Hungarian monarchy.

On September 10, 1919, in the suburbs of the French capital, the suburb of Saint-Germain-enLaye, a peace treaty was signed between the Entente countries and Austria, which, as an ally of the defeated Germany, suffered very serious territorial, economic, financial, human, moral and other losses. As an ultimatum, it was ordered to strictly implement many extremely tough and painful sanctions.

In particular, from now on, the territory of the newly formed small state was only 84 thousand square kilometers, and the population was about 6.7 million people. In addition, Austria, as the losing party, lost the Adriatic coast forever, as a result of which it lost the entire military, commercial and fishing fleet.

Also, on the basis of Article 120 of the said agreement, it was forbidden to have an armed force of more than 30 thousand soldiers. Army formations were to be completed exclusively on a voluntary basis and were intended only for the maintenance of internal order.

Since, in accordance with Article 144 of the signed treaty, Austria was forbidden to have chemical weapons, tank units and combat aircraft, from now on its armed forces consisted exclusively of infantry formations that did not pose a threat to its European neighbors (Gafurova \& Zuboka, 1960).

Another unconditional condition on the part of the winners was a directive on the establishment of a democratic republic in the country. Not only for most politicians, but also for ordinary citizens, this was a surprise, because in the past history Austria had a centuries-old monarchical form of government.

In fact, it required not only a decisive revision of the previously existing legislation, but also a radical reorganization of the central and local legislative and executive authorities, the judicial system and law enforcement agencies. To a certain extent, the issue of breaking the national mentality, social consciousness and the psychological mood of citizens was on the agenda.

Subsequent events clearly showed that a significant part of the representatives of various social strata, supported by the clerics, was not ready for such serious challenges and changes. At the same time, the last Austro-Hungarian emperor, Charles I, not only did not give up hope, but also made some attempts to return to the throne.

At the same time, it should be emphasized that the meaning and essence of parliamentarism were quite familiar to the Austrian public from the middle of the nineteenth century. Here, a year after the revolutionary events of 1848 , the first constitution in the history of the state was published, according to which a constitutional monarchy was established in the country.

For many reasons, the original text of this document has been changed several times. The landowners - the nobles and the urban bourgeoisie, the officials and the Catholic Church, the intelligentsia and the military- 


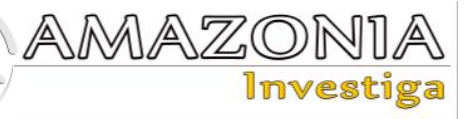

defended their positions. However, after severe conflicts, agreements and mutual concessions since 1867 , in addition to the emperor, who had broad powers, a number of issues of domestic and foreign policy were transferred to the competence of a representative body - the Reichsrat, consisting of the Chamber of Peers and the Chamber of Deputies. Note that these issues, including the use of previously unpublished sources, are quite thoroughly described in the work of O. E. Prudnikov (Prudnikov, 2012, pp. 78-83).

It was against this political, historical and social background, despite the enormous post-war losses and costs, class, group and party divisions, that the Federal Constitutional Law (German: Bundes-Verfassungsgesetz) came into force in Austria on November 10, 1920.

It is important to emphasize that many changes were carried out in an evolutionary way, since those regulatory and legal provisions that adequately met the interests of the citizens of the new state were not discarded. This is evidenced by the fact that in the Republic of Austria, some acts of the monarchy that was a thing of the past were recognized as valid and retained their legal force.

For comparison, it should be recalled that at the same time in Soviet Russia, after the October events of 1917 and the civil war, the nihilistic attitude to the previous system of power and legal thought extended to everything. "In addition to breaking the state machine, the 30-volume code of laws of the Russian Empire also fell into the millstones of the revolution," Yu.S. Vashchenko stated (Vashchenko, 2002, p. 27).

At that controversial period, it was difficult to imagine that the Austrian Federal Constitutional Law would have a long fate, because it is not enough to proclaim advanced doctrines and slogans in legislative form. In such an environment, the main purpose of the State and progressive social forces is to effectively implement the constitutional provisions and to resolutely defend them if necessary.

A textbook example of the purposeful inaction of the highest authorities and the disunity of the anti-fascist movement is the sad experience of the collapse of the democratic principles of the German Weimar Constitution of 1919, which was of sufficient quality for its time.

In Austria in the early thirties, the situation was also very critical. The consequences of the Great economic depression, falling production, low living standards and other negative phenomena contributed to the fact that on May 13, 1932, the leader of the right-wing Christian Social Party, E. Dollfuss, became Chancellor.

Relying on a parliamentary majority and the support of his constituents, he established a strict authoritarian regime, and after the suppression of the uprising of the left opposition forces in February 1934, the above-mentioned Federal Constitutional Law lost its legal force. A new act came into force, called the "May" Constitution (Maiverfassung), from which many positive norms were eliminated or radically revised.

For example, Article 1 of the previous law was excluded, which read: "Austria is a democratic republic. Its right comes from the people." Instead of this fundamental postulate, a slogan was proclaimed, reflecting the position of extremely conservative and clerical circles: "In the name of God Almighty, who grants all rights, the Austrian people received this constitution for their Christian German union state, built on the class principle."

The " May " Constitution was based on the ideas of the so-called "corporate state". An attempt to create it in the Italian Kingdom was made by the dictator B. Mussolini. This borrowing is explained by the fact that E. Dollfuss and his inner circle shared the doctrine of "Italo-fascism" and the corresponding views were actively transferred to Austrian society, which, in the face of severe contradictions, fell on favorable ground.

However, in July 1934, after an unsuccessful putsch by supporters of Hitler's Nazism, the Chancellor died. Formally, the " May " constitution functioned until 1938. Then, as a result of the "Anschluss" (annexation), Austria lost its independence and became an integral part of the German Reich.

Since 1945, Austria has been under the occupation of four victorious powers: the USSR, the United States, Great Britain and France. Ten years later, their allied troops left the country after the adoption of the Declaration of Independence. In accordance with the Federal Constitutional Law of October 26, 1955 (Law, 1955), the permanent neutrality of Austria was declared.

At the same time, by the end of the twentieth century, there were significant deviations from the provisions of the above-mentioned act. In 
1995, the country joined the EU and its military units now take part in the rapid reaction forces of this union. In addition, Austria is included in the program of the NATO military bloc "Partnership for Peace", which already contradicts the meaning and content of the concept of neutrality. Our task does not include a detailed analysis of all the leading conditions of the Federal Constitutional Law of 1920 (Federal constitutional law, 1920). We will briefly comment only on some of the most fundamental requirements that still exist today. It should be noted that at that time, a significant part of the Austrian population perceived them as purely abstract, because in the opinion of ordinary people they were not in harmony with the surrounding reality and the pressing problems of life.

The form of government of the newly formed state was a parliamentary republic, where the highest legislative body was the bicameral Federal Assembly. The Federal Chancellor, as head of government, was accountable to the lower house of Parliament, the National Council. In turn, the head of state, the Federal President, was elected at a joint session of both chambers, but was given purely representative functions, which is typical for parliamentary republics.

In addition to the general rules, the act clearly sets out the characteristics of the three branches of federal power: legislative, executive and judicial; establishes the principle of direct democracy; defines the powers of the legislative and executive authorities of the lands, as well as other areas and issues that are important for society and the state. In our opinion, two aspects deserve special attention among them:

a) this is the legal position of the Audit Chamber - an independent control and supervisory republican body that reports only to the National Council. Its main functions are to check and analyze the financial activities of ministries and departments; other government entities; land and community bodies; legal entities created with the participation of state capital; and to prepare and submit to Parliament a report on the formation and implementation of the country's budget;

b) the above-mentioned law, for the first time in comparison with other subjects of the world community, formulates the status of the Constitutional Court of the Republic of Austria. First of all, this structure, as the highest judicial instance, is called upon to consider questions about the compliance of newly adopted normative legal acts of various legal force with the Basic Law of the country.

The Constitutional Court also has jurisdiction over a number of other narrower and more specific disputes arising between public authorities and other entities, the scope of which is defined in an exhaustive manner and is not subject to broad interpretation.

Here it is necessary to make some digression. In the legislative practice of countries belonging to the Romano-German legal family, to which Austria and Russia belong, it is not customary to focus in any way on the names of specialists who developed and justified certain normative legal acts, even if they were later of primary importance in the life of society and the state. However, when it comes to the Austrian Federal Constitutional Law, as a rule, mention is made of the great personal and scientific contribution made to its preparation by the world-famous lawyer, G. Kelsen (Kelsen, 2006, No. 8, pp. 5-14; Kelsen, 2006, No. 9, pp. 5-18).

He shared the views and theses about the guiding principles of building state power. At the end of the XVIII century raised to a higher level by the famous German thinker I. Kant.

Thus, in his famous work " The Critique of Pure Reason ", the following legal categories are justified:

- the principle of the social contract;

- the principle of popular sovereignty;

- the principle of the rule of law;

- the principle of separation of powers (Kant, 1964).

A detailed analysis of the general and special provisions of the Federal Constitutional Law allows us to assert that, taking into account the existing realities at that time, these concepts somehow received legal consolidation as relevant regulatory provisions.

In our opinion, this is a vivid example when proposals put forward by specific people are separated from their creators, acquire complete independence, individuality and a purely independent, sovereign character. In fact, there is a situation in which the authors can no longer change the current situation and influence it in any way. Their ideas, scientific projects and developments have acquired the form established by law and have become legal instruments in the hands of society and the state. 


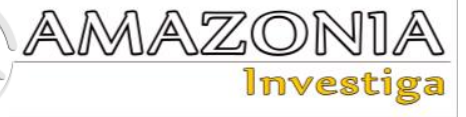

In addition, it was Mr. Kelsen (Kelsen, 2006, No. 8, pp. 5-14; Kelsen, 2006, No. 9, pp. 5-18) who, during the preparation of the analyzed law, comprehensively presented the doctrine of the Constitutional Court, justified its role and significance in the observance of the principles of legality and justice, the protection of rights and socially significant interests. In the future, he developed and defended his position in a number of subsequent studies.

In this regard, the translation of his work "Judicial Guarantee of the Constitution (constitutional Justice)", published in 2006 in the eighth and ninth issues of the journal "Law and Politics" (Kelsen, 2006, No. 8, pp. 5-14; Kelsen, 2006, No. 9, pp. 5-18), is of interest. Interested persons are also addressed to the publication of G. Kelsen "Pure Theory of Law and Analytical Jurisprudence", which was published in the collection "Russian Yearbook of the Theory of Law". No. 2 for 2009 (Kelsen, 2009, pp. 432453).

It should be noted that the general characteristics of both the original and the current concept of Austrian constitutionalism and its constituent elements are presented in the publications of Russian researchers V. V. Novinsk (Novinsky, 2001, pp. 112-116); A. V. Manoilo and I. A. Nizovkina (Manoilo \& Nizovkina, 2014, pp. 180-183); A. Yu. Solomatin and A. S. Koryakina (Solomatin \& Koryakina, 2015, pp.34-41).

Of course, the Federal Constitutional Law, while maintaining the foundation laid in 1920, has now undergone many changes and received additions, caused both by the negative lessons of the past and by quite objective, modern reasons associated with profound changes in European life and in international politics.

For example, in order to exclude the usurpation of power by any party of the parliamentary majority, as was the case in 1934, on the basis of the relevant legal act, the Republic of Austria established a proportional division of ministerial portfolios in the government among all parties that passed the National Council, taking into account the number of parliamentary seats in Parliament.

In turn, the significant additions made to the Federal Constitutional Law in 2008 were due to Austria's accession to the European Union (EU). This led to the voluntary transfer of certain powers in the field of domestic and foreign policy to the governing, supranational structures of this entity.
However, at present, the real situation in the Austrian society is far from ambiguous. There were serious problems in the field of migration quotas imposed on the country from above; disputes in the field of certain industries, mandatory supplies of certain products from abroad; a certain disregard for the national, historical and cultural traditions of the indigenous population, the pressure of the supranational bureaucratic apparatus.

The characteristics of these changes, called the Austrian constitutional reform of 2008, are described in sufficient detail in the dissertation and publications of E. A. Vodianitskaya (Vodyanitskaya, 2011, pp. 193-198); among the Austrian specialists, we will name the monographs Brauneder W., Lachmayer F. (Brauneder \& Lachmayer, 1996); Lien-bacher G. (Lienbacher, 2008).

\section{Methodology}

As one of the leading research methods, the authors were guided by a fundamental dialectical means of cognition: the ascent from the individual to the general. The singular characterizes the immediate certainty of a particular event or phenomenon, emphasizes their individual features, their fixation in time and space. In turn, the general, as a philosophical category, allows us to understand the objectively formed reality, the repeatability of individual properties, events or phenomena, their similarities and relationships.

Based on these factors, the authors, on the basis of individual facts, presented their own, general, unbiased vision of the formation of constitutional principles in Austria and Russia in the past and their current state.

Since the article pays the most significant attention to the events of the past decades, the comparative legal approach, which is a special element of scientific research in the field of state and public institutions of different countries and their legislation, was actively used. Comparison, as a logical technique, is based on a consistent understanding and analysis of similar conditions, rules and requirements. Therefore, we compared the analogous provisions of the Federal Constitutional Law of the Republic of Austria and the Constitution of the Russian Federation. This made it possible to objectively perceive the constitutional principles that deserve attention and support, to weigh their criteria, to establish the similarities and differences between them, on the basis of which to formulate conclusions about 
the most optimal ways to solve the existing problems.

The appeal to the historical and legal method made it possible to present a picture of the events of a century ago, when, after the end of the First World War, a Federal Constitutional Law (Federal constitutional law, 1920) was adopted in Austria, which has passed the test of time and is still in force in its classical part.

In the course of this study, the authors were also guided by the principle of historicism. All the events described in the publication are considered in the movement, development, in their permanent or temporary contacts with other significant factors that relate not only to a specific era of the beginning of the last century. First of all, their inseparable relationship with the time was evaluated.

When preparing the publication, certain elements of the principle of complexity were also taken into account. The meaning of this approach was that some historical facts, certain aspects of constitutional provisions were studied not only from the legal point of view, but also from the philosophical and political positions.

This is manifested in the fact that the cardinal complication of social relations, wars, international and internal conflicts clearly show that even very positive legal ideas implemented in practice need certain clarifications at some point, and if they are fixed in the leading legislative acts: unconditional and effective protection. If there is no such interdependence, then a carefully developed teaching can turn into an immobile amalgam of separate categories, abstract concepts, and strictly abstract truths in a fairly short time.

According to the authors, it is from this point of view that it is necessary to perceive the amendments made to the Basic Laws of the two states. However, you must consider their fundamental differences, which are clearly expressed in the following aspects:

- $\quad$ supplement the Federal constitutional law of the Republic of Austria, especially due to its membership in the European Union (EU), which resulted in a voluntary transfer of certain powers in the field of internal and foreign policy guidelines, supra-national entities of a given entity;

- meanwhile, the main purpose of the amendments made to the Constitution of the Russian Federation during the national vote held on July 1, 2020, is the implementation and translation into practice of the security and protective conditions of domestic constitutionalism. To illustrate, among the many innovations, we will single out only three of the most fundamental norms aimed at protecting the interests of Russian citizens.

Thus, under the terms of clause 2.1 of Article 67 of the Basic Law, actions or appeals of this kind aimed at alienating part of the Russian territory are not allowed. In accordance with the rules of paragraph "g" of paragraph 1 of Article 72, the institution of marriage as a union of a man and a woman is protected by the State. Due to the requirements of Article 79, decisions of international bodies that contradict the Constitution of the Russian Federation are not subject to implementation on the territory of the country.

In the course of the work, methods of analysis and synthesis were widely used, which are classic and indisputable methods of any scientific research in the field of legal and other humanities.

A constructive and critical approach to the assessment of past and modern state-legal doctrines made it possible to draw attention to the role of well-known theorists in the history of the creation of the Federal Constitutional Law of the Republic of Austria and the Constitution of the Russian Federation.

The purpose of the research is to identify and fix the general and specific elements of Austrian and Russian constitutionalism, as well as the regularities of their historical and legal interaction at the current stage of state and social development. Ultimately, the creative application of various research methods and techniques allowed us to solve the problems faced by the authors of the proposed publication.

\section{Results and discussion}

Ultimately, the current Austrian Constitution can be viewed in two dimensions. In the narrow sense of the word, this is the Federal Constitutional Law of November 10, 1920 (Federal constitutional law, 1920). In the broad perception, it is a conglomerate that unites more than three hundred normative legal acts containing certain constitutional requirements, through which a significant range of the most important public relations is regulated. 


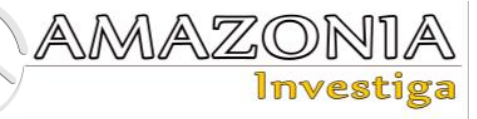

If we talk about modern Russia, the adoption of its Basic Law took place with a significant gap in time in a different political, economic and social environment. However, there were certain, similar circumstances. This is the collapse of the USSR, the extremely difficult economic situation in the country, a sharp drop in the standard of living of the country's population, rampant crime, the confrontation between the entourage of President Boris Yeltsin and supporters of the Supreme Soviet of the Russian Federation, which resulted in the dramatic events of October 1993, which caused human casualties.

Nevertheless, on December 12 of the same year, the Constitution of the Russian Federation was approved by a national referendum and entered into official force. As in the Austrian Federal Constitutional Law, it is based on the principles of democracy and equality; legality and justice; federalism and the separation of powers; the subjects of competence and powers are divided between the federal center and the authorities of the subjects; the institutions of private property and entrepreneurship have acquired a legal status.

The Basic Law also does not contain any ideological guidelines that fix the priority of a particular political party or social movement, and excludes a class approach to various social strata and groups.

At the same time, the norms of the Constitution of the Russian Federation, which occupies a leading place in the hierarchy of laws and bylaws, are not blind copies of foreign standards, since they contain very significant features that emphasize their specificity and originality. Let's look at some conditions in more detail.

First of all, the Basic Law highlights the provisions that the highest value of the Russian state is the person, his rights and freedoms: political, economic, social, cultural, ecological; freedom of movement and occupation; choice of place of residence and freedom of religion.

When analyzing the federal structure of Russia, first of all, it is necessary to pay close attention to its uniqueness. The corresponding entity is created on a national-territorial basis. It unites dozens of peoples and nationalities living on a vast territory, located in different time zones and climatic conditions. Therefore, the structure of state authorities and local self-government bodies has its own distinctive features.
Thus, the republics that are part of a single state have their own constitutions, which reflect the issues inherent in a particular subject of the Federation. If necessary, the specifics of the relationship between the center and other population groups are regulated by separate laws. As an example, the Federal Law of the Russian Federation No. 82-FZ of April 30, 1999 (as amended on July 13, 2020) "On Guarantees of the rights of Indigenous small-numbered Peoples of the Russian Federation" (Law № 82-FZ, 1999) which recognizes independent ethnic communities numbering less than fifty thousand people.

The law takes into account the historical experience of their ancestors in the field of nature management, the original social organization of living and the original culture. The state pays special attention to the preservation of the customs and beliefs of this category of Russian citizens, the protection of the native habitat of the traditional way of life, economic activities and crafts. The bodies of territorial public selfgovernment of indigenous small-numbered peoples play a certain positive role in this.

In our opinion, the above-mentioned act not only declares, but also develops and concretizes the previously proclaimed constitutional principles of legality, justice and equality, public culture and morality. The value of a person, regardless of his nationality, lifestyle and status, is emphasized. At the same time, the State assumes responsibility for the economic support of small indigenous peoples.

It can be stated that a certain decentralization and significant independence of the regions is balanced by the fundamental principles presented in the Basic Law, designed to guarantee the inviolability of the territorial community and the indivisibility of the Russian state. Among them, the following basic principles can be distinguished:

a) equality of the subjects of the Federation in relations with the highest state authorities and among themselves, regardless of historical, economic, national and other features and differences;

b) unity and protection of the foundations of the state system of the Russian Federation;

c) the undisputed priority of federal legislation over regional regulations;

d) the inadmissibility of actions aimed at changing the territorial integrity of the Russian state. 
Unlike Austria, the Russian Federation has a presidential republic as a form of government, in which the head of state has the broadest powers. It is the guarantor of the Basic Law, the rights and freedoms of citizens; determines the main directions of domestic and foreign policy; ensures the coordinated functioning and interaction of state authorities.

In addition to the President, these include the bicameral Federal Assembly (the Federation Council and the State Duma), the Government of the country and its courts at all levels, based on the terms of Article 11 of the Constitution of the Russian Federation. At the same time, as the Supreme Commander-in-Chief, the President of Russia bears personal responsibility for the protection of its state sovereignty, the inviolability of its borders, and the protection of the country from external challenges and threats. It should be emphasized that such an exceptional legal position of the President of the Russian Federation has been subjected to numerous attacks. At the same time, it is necessary to recognize that this form of government largely contributed to overcoming many of the centrifugal processes that engulfed Russia on the verge of two centuries.

Such critical phenomena included the "parade of sovereignty"; the adoption of various regulations in the regions that fundamentally contradict the requirements of the Constitution of the Russian Federation and other federal laws; attempts to infringe on the electoral rights of non-indigenous citizens in certain republics; the introduction of illegal taxes and fees, as well as other negative aspects.

The events in the North Caucasus, which resulted in a violent confrontation with separatism, became the apogee, threatening the real destruction of the Russian statehood. This led to the large-scale involvement of the country's armed forces in combat operations with the enemy.

In this situation, the President of the country and the federal authorities had to immediately make quick and energetic decisions, the implementation of which was carried out only by force. It seems that under the parliamentary form of government, many pressing problems could be drowned in endless debates, agreements and disputes between representatives of various parties, lobbying groups and other similar structures.
The support of a significant part of Russian citizens for the presidential form of government is explained by a number of reasons that go back to the distant past. In particular, it is necessary to take into account the uniqueness, originality and other most significant traditions of Russian society: communality, sobornost, power, patriotism, a special understanding of justice (Gogin, 2016, pp. 34).

In our opinion, regardless of the change of generations and the passage of time, the ideas of paternalism that are ingrained in the minds of people somehow have an impact on the consciousness and behavior of people, which in no way can be perceived in a negative way. History shows that often the role of the subjective factor was the determining factor in many state and other socially significant achievements. These issues are deeply and thoroughly analyzed in the monographs of S. A. Avakyan (Avakian, 2000); N. A. Bobrova (Bobrova, 2012); V. D. Zorkin (Zorkin, 2019) and many other publications.

Among the new federal authorities created in Russia on the basis of the constitutional rules were the Constitutional Court of the Russian Federation and the Accounting Chamber. The conditions of their activities and powers are in many respects comparable to the status of the relevant structures in the Republic of Austria.

At the same time, the constitutional provisions are not postulates that have been frozen for many decades, but a living document designed to change under the influence of objective reasons and socially significant requirements in particularly significant situations.

The complex of accumulated problems of various nature, among which a significant place was occupied by gaps in legislation, legal conflicts, the need to specify and clarify a number of conditions, contributed to the fact that in 2020 the Constitution of the Russian Federation underwent significant adjustments. The works of N. M. Dobrynin (Dobrynin, 2020, pp.3-11); S. N. Baburin [20, pp. 3-8]; A.V. Bezrukov (Baburin, 2020, pp. 3-9] and many other researchers are devoted to the current state of Russian constitutionalism, especially in the context of the reform of 2020.

The complex of accumulated problems of various nature, among which a significant place was occupied by gaps in legislation, legal conflicts, the need to specify and clarify a 


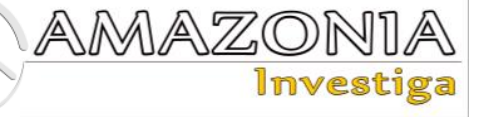

number of conditions, contributed to the fact that in 2020 the Constitution of the Russian Federation underwent significant adjustments. The works of (Dobrynin, 2020, pp.3-11); S. N. Baburin (Baburin, 2020, pp. 3-8); A.V. Bezrukov (Bezrukov, 2020, pp. 3-9) and many other researchers are devoted to the current state of Russian constitutionalism, especially in the context of the reform of 2020.

In addition to the changes indicated at the beginning of the publication, it is necessary to briefly describe several other amendments that are of primary importance, because in the near future they will play their role and will have an impact not only on the daily state of affairs, but also on the future.

First of all, we note a very significant expansion of the powers of the President of the Russian Federation in the field of public administration. In particular, he can not only attend a cabinet meeting, but also carry out "general management" of the government's activities; appoint and dismiss the heads of federal executive bodies, including the ministers of the security sector and foreign affairs; the Prosecutor General and his deputies, and regional prosecutors.

When evaluating other innovations, the content of paragraph 2 of Article 67.1 of the Constitution of the Russian Federation deserves special attention. It is stated here that the Russian Federation, united by a thousand-year history, preserving the memory of our ancestors who passed on our ideals and faith in God, as well as continuity in the development of the Russian state, recognizes the historically established state unity. Many critical comments have been made about this article, but, in our opinion, there is a serious moral potential here, which must be consistently developed in theory and in practice.

\section{Conclusion}

In both countries, the adoption of the Basic Laws was preceded to some extent by similar, negative events of different levels. For the Republic of Austria, the decisive factor was the defeat of the Austro-Hungarian monarchy in the First World War and the formation of several independent states on its former territory. For the Russian Federation, this is the collapse of the Soviet Union caused by a complex of objective and subjective reasons.

The foundation of the constitutionalism of both countries is made up of the principles of democracy and equality, legality and justice, federalism and separation of powers, protection of the rights, welfare and diverse interests of citizens, as well as other value aspects designed to determine the main directions of life and development of modern society.

At the same time, each state, due to a huge range of specific features, has the right to fix in its laws those conditions and provisions that meet the social needs of the country's population, even if they may be perceived in certain elements by other subjects of the world community in a controversial and ambiguous way.

\section{References}

Avakian, S. A. (2000). The Constitution of Russia: nature, evolution, and modernity. 2nd ed., Moscow: Sashko RYUID.

Baburin, S. N. (2020). On the spirituality of the goals and sociality of the tasks of the Russian constitutional reform. Constitutional and Municipal Law, No. 4, pp. 3-8.

Bezrukov, A.V. (2020). Constitutional reform the main directions and ways to improve the configuration of public power in Russia. Constitutional and Municipal Law, No. 4, pp. 3-9.

Brauneder, W., \& Lachmayer, F. (1996). Austrian constitutional history. Introduction to development and structures. Vienna.

Bobrova, N. A. (2012). Constitutional system and constitutionalism in Russia, Moscow: Unity Dana: Law and Law.

Dobrynin, N. M. (2020). Constitutionalism and the paradigm of public relations in Russia: historical experience, conformism or the inevitability of change. Constitutional and Municipal Law, No. 1, pp. 3-11.

B. y. (1957). International relations and foreign policy of the USSR (1871 - 1957) M: Sat. doc.

Federal constitutional law. "Constitution of the Republic of Austria" Austrian federal constitutional law of November 10, 1920 (as amended in 1999). https://legalns.com/download/books/cons/austri a.pdf

Federal Law of the Russian Federation No. 82FZ "On Guarantees of the rights of Indigenous small-numbered Peoples of the Russian Federation". Collection of legislation of the Russian Federation, Russian Federation, of April 30, 1999 (as amended on July 13, 2020).

Gafurova, B. G., \& Zuboka, P. I. (1960). A textbook on modern history in three volumes. Volume 1. (1917-1939 Documents and Materials), Moscow: Publishing House of SocioEconomic Literature. 
Gogin, A. A. (2016). Offense: general theoretical, intersectoral and branch aspects: monograph, Moscow: Yurlitinform.

Kant, I. (1964). The Critique of Pure Reason. Essays in six volumes. Vol. 3. Publishing house of socio-economic literature, Moscow: "Thought".

Kelsen, G. (2006). Judicial guarantee of the Constitution (constitutional justice). Part 1. Law and Politics, Moscow: NOTA BENE, No. 8, pp. 5-14.

Kelsen, G. (2006). Judicial guarantee of the Constitution (constitutional justice) Part 2. Ending. Law and Politics, Moscow: NOTA BENE, No. 9, pp. 5-18.

Kelsen, G. (2009). Pure doctrine of law and analytical jurisprudence. Perev. from the English by A. A. Kraevsky. Russian Yearbook of the Theory of Law, No. 2, pp. 432-453.

Lienbacher, G. (2008). The first part of the constitutional reform. Journal of Research Practice.

Manoilo, A.V., \& Nizovkina, I. A. (2014). Features of Austrian federalism. International Relations, No. 2, pp. 180-183.
Novinsky, V. V. (2001). Evolution of the constitutional legislation of the Republic of Austria. Russian Law Journal, No. 1(29), pp. 112-116.

Prudnikov, O. E. (2012). Formation of the foundations of the constitutional legislation of the Austrian Imperial Monarchy in the 18661867 - ies. Bulletin of the Volgograd State University. Series 5: Jurisprudence, No. 1(14), pp. 78-83.

Solomatin, A. Yu., \& Koryakina, A. S. (2015). Austrian federalism. Science, Society, State, 3(4), pp. 34-41.

Vashchenko, Yu. S. (2002). Philological interpretation of the norms of law: a monograph. Tolyatti: Publishing House of the V. N. Tatishchev Volzhsky University.

Vodyanitskaya, E. A. (2011). The 2008 Austrian Constitutional Reform. MGIMO Bulletin, No. 4, pp. 193-198.

Zorkin, V. D. (2019). Constitutional and legal development of Russia. Monograph, M.: Norma. 